\title{
RESERVA DO PLENÁRIO E A (IN)SEGURANÇA JURÍDICA: ANÁLISE DA SÚMULA VINCULANTE NUUMERO 10
}

\author{
PLENARY RESERVATION AND LEGAL SAFETY: \\ ANALYSIS BINDING PRECEDENT NUMBER 10
}

\author{
Giovane Moraes Porto* \\ Luís Henrique Barbante Franzé**
}

\begin{abstract}
Resumo: No intuito de minimizar a insegurança jurídica e a falta de isonomia trazida pelas decisões judiciais conflitantes sobre a mesma matéria, foi editada a Súmula Vinculante $\mathrm{n}^{\circ} 10$, que obriga a reserva de plenário mesmo quando o pronunciamento proferido por órgão fracionário de tribunal não reconhecer a inconstitucionalidade da norma expressamente. Mas, esta súmula perderá a sua finalidade se não houver um critério para assegurar que seja aplicada ao mesmo fato que lhe deu origem. Assim, o objetivo desta pesquisa é buscar, na cultura da "common law", critérios da "ratio decidendi" que gerem maior confiabilidade na aplicação da referida súmula, além de propor uma nova redação. Será usada a pesquisa doutrinária e jurisprudencial, inclusive originária da cultura da "common law". É esperado chamar atenção dos juristas para a importância do debate sobre a necessidade de maior segurança jurídica e igualdade, notadamente, por meio da aplicação da Súmula Vinculante $\mathrm{n}^{\circ} 10$.
\end{abstract}

Palavras-chave: "Ratio decidendi”; Súmula vinculante; Segurança jurídica; Isonomia; Reserva de plenário.

\begin{abstract}
In order to minimize legal uncertainty and the lack of equality brought about by conflicting court decisions on the same matter was issued Binding Precedent $n^{\circ} 10$, which requires the reservation plenum even when the speech given by fractional referring court does not recognize the unconstitutionality of the norm explicitly. But, this summary will lose its purpose if there is no criteria to ensure that it is applied to the same facts that gave rise. The objective of this research is to look at the culture of "common law" criteria "ratio decidendi" that generate greater confidence in applying that precedent, as well as propose a new wording. Doctrinal and jurisprudential research, including original culture of "common law" will be used. It is expected to draw the attention of law enforcement officers to the importance of the debate on the need for greater legal certainty and equality, notably through the implementation of Binding Precedent $n^{\circ} 10$.
\end{abstract}

\footnotetext{
* Mestrando e Graduado em Direito pelo Centro Universitário Eurípides de Marília - UNIVEM. Integrante e monitor do grupo de pesquisa Constitucionalização do Direito Processual (CODIP), vinculado ao CNPq-UNIVEM. Advogado. Contato: e-mail: giovanemoraesporto@ hotmail.com.

** Pós-Doutor em Direito pela Faculdade de Direito da Universidade de Lisboa. Doutor em Processo Civil pela PUC-SP. Mestre em Direito pela Faculdade de Direito de Bauru. Professor no programa de mestrado da Fundação de Ensino Eurípides Soares da Rocha em Marília (UNIVEM) e no programa de graduação da Universidade Metodista de Piracicaba (UNIMEP). Vice-líder do Grupo de Pesquisa Constitucionalização do Direito Processual (CODIP). Advogado. E-mail: lhbfranze@ gmail.com.
} 
Keywords: "Ratio Decidendi"; Binding Precedent; Legal Certainty; Equality; Plenary Reserve

\section{INTRODUÇÃO}

O tema foi escolhido, porque um dos grandes obstáculos da ciência jurídica é a busca por mecanismos que venham a uniformizar - o máximo possível - as decisões judiciais sobre temas similares, para que os jurisdicionados tenham maior isonomia, segurança jurídica e justiça formal ${ }^{1}$. No entanto, conforme a cultura jurídica de cada povo, a uniformização tem sido buscada de modo diferente.

Assim, em um primeiro momento, este estudo examinará os precedentes e as suas regras relacionadas ao seu elemento vinculante, isto é, a "ratio decidendi". Após, serão verificadas as diferenças e peculiaridades da realidade brasileira, já que o sistema jurídico brasileiro, gradativamente, tem aumentado a força normativa das decisões judiciais, de modo que a experiência jurídica, de alguns pronunciamentos judiciais, passa a ser considerada como uma fonte primária do Direito, tal como ocorre com a súmula vinculante.

O instituto do precedente judicial é muito confundido, no Brasil, com o instituto das súmulas vinculantes. Assim como a jurisprudência, estes dois institutos decorrem do poder judiciário e vinculam as futuras decisões. Porém, para fazer uma diferenciação mais precisa é necessário verificar qual elemento da súmula vinculante que possui a força vinculante.

A doutrina não é pacífica quanto ao elemento vinculante das súmulas, uns entendem que é só o enunciado, outros entendem que é o enunciado juntamente com os casos que deram origem à súmula, pois todas as súmulas precisam ser baseadas, derivadas, de casos concretos.

A corrente doutrinária que entende que a parte vinculante da súmula vinculante é o enunciado (texto), juntamente com os casos que deram origem a súmula, entende não ser possível diferenciar os institutos afirmando que o precedente está ligado a um caso concreto em quanto às súmulas não, pois entendem que as súmulas não se desligam dos casos que lhe deram origem.

Sendo assim, apesar da súmula ser diferente do precedente pelo fato que aquela visa à solução de casos futuros e este visa à solução de um único caso passado, é possível a utilização de alguns elementos da teoria do precedente judicial no instituto 
Reserva do plenário e a (in)segurança jurídica: análise da Súmula Vinculante número 10 das súmulas. Principalmente, as técnicas da "ratio decidendi" e "obter dictum", do "overruling" e do "distinguish".

A extração da "ratio decidendi" não estaria no enunciado da súmula, mas nos casos concretos que deram origem às súmulas, assim como a técnica do "distinguish" consistiria na diferenciação do caso a ser solucionado com os casos que deram origem à súmula. A técnica do "overruling" consiste no fato de superar o(s) argumento(s) utilizado(s) para a solução dos casos que deram origem à súmula.

A utilização desses elementos da teoria precedente judicial no instituto das súmulas vinculantes consiste em uma das mais importantes interações entre a "common law" e a "civil law". Por isso, analisar-se-á o novo Código de Processo Civil, com o escopo de verificar a presença de elementos da "common law" nesta legislação.

Ao final, será possível propor um critério mais próximo possível da realidade brasileira, para buscar pela "ratio decidendi" da Súmula Vinculante n 10 , que dispõe sobre a reserva do plenário.

No mais, esta pesquisa não tem a pretensão de esgotar o tema, mas apenas de trazer informações que instiguem o debate, notadamente, sobre a segurança jurídica trazida pela aplicação da súmula vinculante. A metodologia utilizada foi de caráter dedutivo utilizando a pesquisa bibliográfica como fonte de observação teórica.

\section{BUSCA PELA IGUALDADE E SEGURANÇA JURÍDICA NA "COMMON LAW"}

A cultura jurídica da "common law" - de origem anglo-saxônica -, é consuetudinária (BOBBIO, 1995, p. 33), ou seja, não é necessariamente escrita, além de ser pautada pelos usos e costumes que devem ser reconhecidos formalmente pelas autoridades judiciárias. A principal fonte do direito desta cultura é o precedente judicial que se torna parâmetro para tutelar os futuros casos análogos (MANCUSO, 2007, p. 174), com o propósito de gerar igualdade ${ }^{2}$ e segurança jurídica aos jurisdicionados, implicando maior coerência entre o passado e futuro do sistema. Por consequência, a cada novo problema jurídico o Direito passa a ser reformulado pelo Poder Judiciário ("from case to case"), outorgando poder normativo, ao Judiciário, para a construção do Direito. 
Aliás, a "common law" (também conhecida como "comune ley") foi estabelecida como meio para combater a grande variedade dos costumes, que variavam de local para local, com a função de propiciar um direito comum sobre toda a Inglaterra. Inicialmente a "common law" passou a ser aplicada com exclusividade pelos Tribunais Reais de Justiça, que tinham o monarca no topo da hierarquia (DAVID, 2002, p. 359) e, apesar do formalismo inicial, gradativamente, as decisões passaram a ser normas substantivas, de modo que o precedente foi valorizado ${ }^{3}$ (DAVID, 2002, p. 364).

Vale registrar que a "common law" sofreu forte influência do período relativo à conquista da Inglaterra (anglo), pelos normandos (saxões), que eram capitaneados por Guilherme, o Conquistador, no ano de 1066 (DAVID, 2002, p. 358). Daí porque é dito que a “common law” é anglo saxônica.

Logo - ao contrário da "civil law", que chegou a proibir a interpretação das leis pelo juízo -, a "common law” vem aprimorando a interpretação judicial há séculos e, por isso, possui mecanismos que não podem ser desprezados pela "civil law" para gerar maior igualdade e segurança jurídica. Um dos seus principais mecanismos é o precedente e a respectiva teoria da "ratio decidendi".

O substantivo "precedente" não guarda relação com "jurisprudência", já que - como lembrado por Michelle Taruffo (2007) -, existem duas grandes diferenças, a saber: a) quantitativa, pois o precedente versa sobre um caso particular, enquanto a jurisprudência implica a pluralidade de decisões; b) qualitativa, pois o precedente é melhor elaborado, já que estabelece uma regra a ser universalizada para casos futuros similares, enquanto a jurisprudência se satisfaz em interpretar regras jurídicas ${ }^{4}$.

Por outro lado, o conceito de precedente não é pacífico. Por exemplo, para Thomas da Rosa de Bustamante (2007) consiste em qualquer decisão judicial prévia que um juiz se embasa para fundamentar o seu pronunciamento sobre um caso atual. Já, para Luiz Guilherme Marinoni (2013), será a decisão judicial que elabora uma tese jurídica. Após trazer conceito parecido, Caio Márcio Gutterres Taranto (2010) acrescenta que o precedente tem a função de atribuir racionalidade ${ }^{5}$.

Enfim, com apoio nesta última definição, para este estudo, precedente será considerado como a decisão prévia que elabora tese jurídica para atribuir racionalidade ao sistema.

Vale ressaltar, ainda, a existência de duas teorias sobre o âmbito dos precedentes. 
Reserva do plenário e a (in)segurança jurídica: análise da Súmula Vinculante número 10

Uma é a teoria declaratória, que defende a existência de um direito (inclusive trazido pelos costumes) anterior ao precedente, de modo que o precedente apenas declara um direito que já existe. Um dos expoentes desta teoria é William Blackstone (1979).

Outra é a teoria constitutiva, que defende a inexistência de um direito anterior ao precedente, de modo que o precedente cria o direito (“judge make law”). Esta corrente é defendida por Oliver Wendell Holmes (1982) e Roscoe Pound (1937). Esta teoria tem maior aceitação.

Os precedentes, apesar de configurarem fontes do direito, não estão acima da lei. Estão limitados ao quadro normativo imposto pelo legislativo, por isto é uma forma de limitação à discricionariedade. Porém, mesmo com a discricionariedade limitada há o reconhecimento, a criação, do direito. Sempre haverá margem para a discricionariedade, se fosse possível extinguir toda a discricionariedade poderiam substituir os julgadores por computadores.

\footnotetext{
Os precedentes não se situam acima da lei, mas são apenas interpretações dessa lei. É claro que existe a discussão entre as teorias declaratórias e constitutivas acerca da possibilidade de o juiz criar o direito, mas de qualquer forma, ainda que ele possa, por decisão judicial, criar o direito, estará ele obviamente submisso à vontade do legislador se o "direito criado judicialmente" foi legislativo por quem de direito (NOGUEIRA, p. 200).
}

O debate entre a teoria declaratória e a teoria constitutiva ou positivista é muito importante para a teoria jurídica, a fim de analisar a genealogia do direito. A teoria declaratória entende que o direito preexiste à decisão judicial, esta apenas reconhece e atribuí o dever de obediência, limitada às prescrições legislativas.

Ao passo que, a teoria constitutiva ou positivista, entende que a decisão judicial que determina a proveniência do direito, o direito não preexiste, só será considerado direito a partir da decisão judicial.

Nas duas teorias há a vinculação da decisão judicial, há a subordinação ao conhecimento produzido pela decisão, à atribuição de significado ao texto normativo e o dever de observância.

Da teoria positivista podemos extrair a afirmação - geralmente correta - de que os juízes têm determinado poder criativo ao interpretar e aplicar o Direito aos casos concretos; da teoria declaratória podemos derivar a tese de que, em um importante sentido, os juízes, quando aplicam o Direito a determinado caso concreto, estão vinculados pelo conteúdo das prescrições normativas 
que podem de modo geral ser derivadas do Direito e de sua sistematização racional (BUSTAMANTE, 2012, p. 264-265).

A teoria que prevalece é a teoria constitutiva ou positivista do direito. Apesar de o precedente estar limitado ao quadro normativo, este não possui significado por si, necessita de um discurso racional feito por meio de uma decisão judicial para atribuir significado ao texto normativo, ou seja, para "preencher" o quadro. Portanto, o julgador não apenas declara algo que já existia, ele constitui, cria, o direito, mesmo tendo a discricionariedade limitada por esta moldura. $\mathrm{O}$ que preexiste é a moldura a ser preenchida, não o direito propriamente dito.

Uma vez definido precedente, já será possível verificar uma das principais regras sobre o mesmo, isto é, a "ratio decidendi". A "ratio decidendi" é um fragmento da decisão que irá servir de parâmetro para o julgador em casos futuros, a fim de analisar se os casos se assemelham, analisar os motivos deterrminantes para a decisão e, se for o caso, superar o argumento anterior, superar a norma anterior.

Para que uma opinião tenha o peso de um precedente é necessário que ela tenha sido dada por um juiz e também que tenha sido necessária para a decisão de um caso particular, isto é, não pode ser "obiter dictum”. A "ratio decidendi" de uma decisão nos sistemas de "common law" é o que vai criar um precedente vinculante nas decisões seguintes e, portanto, se faz necessário descobri-la (BARBOZA, 2014, p. 217).

Para localizar a "ratio decidendi" em uma decisão judicial é necessário reconstruir subsuntivamente/silogisticamente a justificação racional, para verificar a relação entre as suas premissas e o resultado do julgamento. A fim de verificar quais são os argumentos que sem eles não seria possível chegar naquele resultado do julgamento.

Tal reconstrução pressupõe, antes de tudo, uma ferramenta analítica para elucidar a estrutura das decisões judiciais e revelar todas as premissas normativas contidas em sua fundamentação. Tal ferramenta analítica pode ser a enunciação formal dessas premissas normativas sob a forma de silogismos práticos, isto é, silogismos "cuja premissa maior e cuja conclusão não são enunciados que se assume exprimirem proposições apofânticas, mas enunciados que se assume exprimirem proposições prescritivas" [Chiassoni 1999:152] (BUSTAMANTE, 2012, p. 278).

Deste modo, o elemento da decisão que não influiu no resultado do julgamento é chamado de "obter dictum" e não vinculará os demais julgamentos. Já a parte da decisão que foi decisiva para o resultado do julgamento será a "ratio decidendi”. Portanto, é possível a presença de mais de um argumento que interfira no 
Reserva do plenário e a (in)segurança jurídica: análise da Súmula Vinculante número 10

resultado do julgamento, podendo conter "rationes decidendis". "A dificuldade para determinar a ratio decidendi de um caso qualquer decorre, em minha opinião, da pressuposição de que há apenas uma ratio em cada caso julgado". (BUSTAMANTE, 2012, p. 270). Entre as "rationes decidendi" podem haver diferentes graus de vinculação, a chamada "força gravitacional" 6 pode variar entre as rationes.

Precedentes judiciais são, como enunciados legislativos, textos dotados de autoridade que carecem de interpretação. É trabalho do aplicador do Direito extrair a ratio decidendi - o elemento vinculante - do caso a ser utilizado como paradigma. Mas a noção de ratio decidendi e os critérios para sua determinação contituem algo ainda fortemente controvertido. Talvez este seja o ponto mais polêmico da teoria dos precedentes e de toda a teoria jurídica produzida no common law (BUSTAMANTE, 2012, p. 259).

A “obter dictum” - o elemento não vinculante de um precedente judicial - é verificada na justificação da decisão por exclusão, ou seja, aqueles argumentos que não são considerados ratio decidendi, não influenciam o resultado do julgamento ${ }^{7}$, são considerados obter dictum, por isso "dito para morrer".

De modo geral, o conceito de dictum é definido per exclusionem: todas as normas e afirmações que não puderem ser enquadradas no conceito estrito de ratio decidendi têm sua autoridade descartada e valem apenas pela força de convencimento que eventualmente possam vir a ter [Marshall 1997:515; Taruffo 1994:420]. (BUSTAMANTE, 2012, p. 276).

Portanto, a análise da ratio decidendi é muito importante para a teoria jurídica, pois é o elemento que irá constuir o direito de forma racional, construir o entendimento jurisprudencial, impor o conhecimento a ser seguido. A fim de gerar coerência, previsibilidade, integridade, segurança e estabilidade de entendimento no sistema jurídico.

No entanto, conforme aponta Marcelo Alves Dias de Souza (2013), existem algumas teorias para localizar a "ratio decidendi" da decisão, tais como: pela teoria de Eugene Wambaugh (conhecida como teoria clássica), a "ratio decidendi" será a proposição necessária para uma decisão; pela teoria de Herman Oliphant, a "ratio decidendi" serão os fatos existentes nos autos que estimularam a resposta do tribunal, devendo ser ignorado o trabalho mental usado, na decisão, pelo juiz e; pela teoria de Arthur Goodhart, a "ratio decidendi" consiste nos fatos que o juiz considerou como fundamentais ("material facts") para a sua decisão. Assim, o primeiro passo seria a 
identificação dos fatos jurídicos relevantes e, a partir daí, se passa ao desenvolvimento das regras para esta busca ${ }^{8}$.

O problema da teoria de Herman Oliphant é que se mostra ilógica esta separação entre o trabalho mental do juiz e os fatos que estimularam a conclusão. Aliás, é difícil imaginar - para não dizer impossível -, que possa haver esta separação.

Já, para a teoria de Arthur Goodhart - que, grosso modo, procura aprimorar a teoria de Eugene Wambaugh -, a "ratio decidendi" pode ser conceituada como os fatos considerados pelo pronunciamento (antecedentes) que conduziram efetivamente ao resultado da decisão (consequente) ${ }^{9}$.

Por exemplo, a Súmula $n^{\circ} 701$ do Supremo Tribunal Federal expressa que: "No mandado de segurança impetrado pelo Ministério Público contra decisão proferida em Processo Penal, é obrigatória a citação do réu como litisconsorte passivo.”

Logo, para aplicar a teoria dos precedentes para casos futuros, deverão ser comparadas as semelhanças entre as situações de fato ("ratio decidendi") que obrigarão ao resultado, ou seja, se o caso atual: a) versa sobre impetração de mandado de segurança; b) e, se o ato coator consiste em decisão judicial proferida em processo penal.

Se ambos os fatos (antecedentes) ocorrerem, então deverá ser considerado o resultado (consequente), isto é, que haverá obrigação de citar o litisconsorte passivo ${ }^{10}$.

A "ratio decidendi" não é utilizada apenas para a aplicação do precedente, mas também para a sua justificação, fazendo com que o precedente se vincule mais pela "ratio" do julgado que pela sua autoridade ("autorictas"), diminuindo a discricionariedade judicial.

\section{SÚMULA VINCULANTE NO BRASIL}

A cultura da "civil law" sofreu forte influência da revolução francesa, que buscou preservar a igualdade e segurança jurídica, por meio da proibição de que o juiz interpretasse a lei, sendo permitido, apenas, que declarasse a vontade do legislador.

Os franceses tinham receio de que os juízes, por serem originários da nobreza, poderiam decidir com parcialidade. Daí, porque Charles de Secondat Montesquieu defendia que os juízes eram apenas a boca da lei ("bouche de la loi”), de modo que, ao aplicarem a lei: "não podem moderar nem sua força nem seu rigor" (MONTESQUIEU, 1979, p. 160). Portanto, a aplicação se dava de forma puramente 
Reserva do plenário e a (in)segurança jurídica: análise da Súmula Vinculante número 10 mecânica. De modo que, se o juiz necessitasse interpretar a lei, deveria pedir para que o Legislativo fizesse previamente esta interpretação.

Em outras palavras, a "civil law" partiu da premissa de que as situações tipificadas pelas leis - além de refletirem todos os ideais de justiça e moral - seriam suficientes para prever a solução de todos os conflitos que possam acontecer em nosso cotidiano (DAVID, 2002, p. 23), isto é, que o sistema teria coerência e completude, sem lacunas ou conflito entre as normas. Dessa forma, a aplicação da lei pelo juiz, sem interpretá-la, implicaria a isonomia e segurança jurídica dos jurisdicionados ${ }^{11}$.

No Brasil, embora a nossa Constituição Federal ainda mantenha a necessidade de obediência à lei ${ }^{12}$, é sabido que este critério da "civil law" tem sofrido grandes mitigações ${ }^{13}$, levando o juiz a interpretar a lei.

Mas aí é que surge o problema da falta de limites para esta interpretação, que tem levado às inúmeras decisões conflitantes para casos similares, desnorteando os jurisdicionados e, por conseguinte, ofendendo a isonomia e segurança jurídica.

Atualmente, o juiz brasileiro tem mais poder do que o juiz da "common law", já que pode interpretar a lei e não está limitado pelos precedentes. Emerge daí a importância de que a decisão judicial demonstre claramente as premissas que levaram ao resultado, de modo semelhante à "ratio decidendi" na "common law"14.

O ordenamento jurídico brasileiro, concebido a partir da "civil law", vem demonstrando simpatia crescente pelas tentativas de uniformizações sobre determinados temas proferidos pelo judiciário.

Em interessante retrospecto histórico, Caio Márcio Guterres Taranto (2010, p. 23) aponta as quatro principais fases históricas que marcam este processo gradativo de aumento das uniformizações da jurisprudência.

A $1^{\mathrm{a}}$ fase ocorreu entre os anos de 1500 e 1889 , tendo sido norteada pela influência do Direito Português, uma vez que, no período do Brasil-Colônia, a Lei 2.684/1875 validou os assentos da Casa de Suplicações de Portugal (ALMEIDA, 1885, p. 97), para também serem aplicados no território brasileiro, inclusive quanto à sanção funcional imposta ao juiz que deixasse de aplicar os referidos assentos.

Um aspecto interessante era a possibilidade de o judiciário ser retaliado, pois o inc. VIII do art. 15 da Constituição de $1824^{15}$ dava competência, em último grau, ao legislativo para interpretar as leis (e não ao judiciário), como é próprio da “civil 
law", além de que - grosso modo -, as decisões do legislativo não poderiam ser impugnadas, porque inexistia controle de constitucionalidade para as mesmas.

Mas não pode ser esquecido que este aparente poder do legislativo foi mitigado pelo poder moderador atribuído ao Imperador, que tinha meios para efetivar forte pressão junto aos demais poderes, inclusive podendo dissolver ou substituir a Câmara dos Deputados, bem como suspender magistrados (Constituição de 1824, art. $\left.101^{16}\right)$. A propósito, esta fase tem forte marca da "civil law" no tocante ao enfraquecimento do judiciário, por meio da impossibilidade de o juiz interpretar leis.

A $2^{\text {a }}$ fase se deu entre os anos de 1891 e 1963, tendo sido pautada pela préobjetivação das decisões judiciais relativas ao controle de constitucionalidade pela via difusa, que passaram a ser normas no sentido de terem validade para todos os jurisdicionados (“erga omnes”), indo além das partes que litigam no processo.

Basicamente, esta fase foi iniciada pela Constituição da República de 1891 que - inspirada no modelo estadunidense -, trouxe o controle de constitucionalidade difuso (“judicial review”) ${ }^{17}$, mas deixou de atribuir às respectivas decisões judiciais o necessário efeito vinculante.

Em paralelo, este esboço de força normativa destas decisões inerentes ao controle de constitucionalidade sofreu um duro golpe, pois a lei passou a ter exclusividade como fonte do direito, bem como foi permitido que cada Estado legislasse sobre processo. Esta diversidade de legislações processuais civis, como não poderia deixar de ser, gerou grande gama de decisões judiciais contrárias sobre a mesma questão, ampliando a insegurança jurídica e a ofensa a isonomia dos jurisdicionados.

No intuito de restaurar a força de alguns pronunciamentos judiciais, a Emenda Constitucional de 03 de setembro de 1926 atribuiu a função uniformizadora ao Supremo Tribunal Federal, ao inserir o inc. II do art. 59 da Constituição Federal de $1891^{18}$.

Entretanto, a Constituição de 1937 reduziu o alcance do controle de constitucionalidade difuso, ao permitir que a invalidade pudesse ser revista pelo parlamento, mediante remessa do Presidente ${ }^{19}$. Mas, esta mesma Constituição de 1937 também restaurou a competência da União para legislar sobre processo, acabando com a parafernália gerada pela diversidade de Códigos Processuais Estaduais e criando a figura do prejulgado $\left(\mathrm{CPC} / 39\right.$, art. 861 ${ }^{20}$. 
Reserva do plenário e a (in)segurança jurídica: análise da Súmula Vinculante número 10

O mencionado prejulgado era um incidente para se buscar pela uniformização, porém sem caráter vinculante no processo civil. Esta fase terminou no dia 13 de dezembro de 1963, quando foi inovado o modo de uniformização da jurisprudência, por meio da criação das primeiras súmulas.

Por sua vez, a $3^{\text {a }}$ fase foi estabelecida entre os anos de 1963 a 1988, tendo sido pautada pela objetivação de decisões judiciais que - em algumas situações -, deixaram de ser aplicados apenas aos casos concretos, para abranger a todos.

O início desta fase se deu pela introdução do controle de constitucionalidade concentrado em nosso país, por meio da Emenda Constitucional 16, de 26 de novembro de 1965, que passou a conviver ao lado do controle difuso, que já existia. Daí para frente, o modelo de controle de constitucionalidade concentrado passou a ser ampliado.

Em paralelo, o incidente de uniformização continua até os dias atuais, conforme previsto no art. 479 do $\mathrm{CPC} / 73^{21}$.

Atualmente a força vinculante das decisões judicais vivencia a $4^{\mathrm{a}}$ fase, iniciada em 1988, que passa a reconhecer a condição normativa dos princípios, inclusive, para superar dogmas tradicionais, como permitir que o judiciário atue no caso de omissões do legislador ou do executivo (ativismo judicial ${ }^{22}$ ).

Feito este breve retrospecto histórico, podem ser apontadas algumas situações atuais em que o legislador busca pela força normativa dos precedentes, tais como: A lei 8.038/90 (lei dos recursos), por meio do art. $38^{23}$ - no âmbito do Supremo Tribunal Federal e do Superior Tribunal de Justiça - outorgou poderes ao relator para negar seguimento a recurso manifestamente contrário à súmula. Aliás, posteriormente, esse entendimento foi ampliado para os demais recursos, por meio do art. 557 do CPC/73, com redação das leis 9.139/1995 e 9.756/1998; A emenda constitucional $\mathrm{n}^{\circ}$ 03/1993, alterou a CF/1988, para instituir o efeito vinculante às decisões definitivas de mérito, proferidas na ação declaratória de constitucionalidade $\left(\mathrm{CF}\right.$, art. 102, $\left.\S 2^{\circ 24}\right)$, no âmbito do Supremo Tribunal Federal; A Emenda Constitucional $n^{\circ} 45 / 2004$, instituiu a súmula vinculante (CF, art. 103-A); A lei 11.276/2006 inseriu o $\S 1^{\circ}$ no art. 518 do $\mathrm{CPC} / 73$, para que o juiz não receba o recurso de apelação quando a sentença estiver embasada em súmula do Supremo Tribunal Federal ou do Superior Tribunal de Justiça; A lei 11.672/2008 inseriu os arts. 543-B e 543-C, ambos do CPC/73, que permitem o julgamento por amostragem dos recursos extraordinário e especial, quando versarem 
sobre questão de direito que exista multiplicidade de recursos, de modo que a decisão adotada nos recursos selecionados será aplicada aos demais que versarem sobre a mesma questão; O novo CPC, lei 13,105/2015, possui tipificação para algumas situações de respeito da observância da "ratio decidendi", como a obrigatoriedade de a sentença, interlocutória ou acórdão que invocar "precedente" ou "súmula" venha a identificar a semelhança dos fundamentos determinantes do resultado, com o caso que está sendo apreciado (art. 489, $\S 1^{\circ}$, incs. V e VI).

Certamente a falta de efeito vinculante é a maior diferença entre a súmula persuasiva - também conhecida como súmula simples (NERY JUNIOR, 2006, p. 747) e a súmula vinculante, como defendem Rodolfo de Camargo Mancuso (MANCUSO, 2007, p. 374) e José Rogério Cruz e Tucci (TUCCI, 2004, p. 12).

Porém, gradativamente, o legislador tem ampliado (potencializado) os efeitos da súmula persuasiva, que pode ser usada como fundamento, inclusive, para o juiz não receber apelação $\left(\mathrm{CPC} / 73\right.$, art. $\left.518, \S 1^{\circ}\right)$; para o relator, isoladamente, negar seguimento a recurso $(\mathrm{CPC} / 73$, art. 557) ou mesmo dar provimento $(\mathrm{CPC} / 73$, art. $557, \S$ $\left.1^{\mathrm{o}}-\mathrm{A}\right)$.

Outra diferença é que as súmulas persuasivas podem ser editadas por qualquer tribunal, enquanto as vinculantes competem apenas ao Supremo Tribunal Federal.

$\mathrm{O}$ rito de criação da súmula vinculante está previsto no art. 103-A da CF, que foi regulamentado pela Lei 11.417/2006.

Porém, o objeto da súmula vinculante é limitado, já que apenas poderá ser criada quando houver matéria de natureza constitucional, que tenha sido objeto de reiteradas decisões (CF, art. 103-A, "caput") ${ }^{25}$.

De outro lado, a aprovação da súmula vinculante depende do voto da maioria qualificada ${ }^{26}$ de $2 / 3$ dos seus membros. Desta forma, existindo onze ministros no Supremo Tribunal Federal, é necessário o mínimo de oito votos para a sua aprovação (CF, art. 103-A, “caput”).

Em paralelo, a súmula vinculante também possui penalidades para o seu descumprimento, tais como: O interessado poderá interpor reclamação diretamente ao Supremo Tribunal Federal para postular pelo descumprimento da súmula e, consequentemente, para cassar/anular o ato (Constituição Federal, art. 103-A, § $3^{\circ}$ ) ${ }^{27}$; O 
Reserva do plenário e a (in)segurança jurídica: análise da Súmula Vinculante número 10 infrator da súmula será responsabilizado nas esferas civil, administrativa e penal (Lei 9.784/99, art. 64-B) $)^{28}$.

De fato, de nada adiantaria o efeito vinculante se não houvesse uma forma de coerção. No entanto - e até mesmo para que seja facilitada a sua interpretação e consequente função uniformizadora -, é imprescindível que a súmula vinculante traga, de modo claro e exaustivo, as situações (antecedentes) que devem estar presentes para incidir o resultado (consequente), conforme será melhor explicado no próximo item.

\section{SÚMULA VINCULANTE 10}

O princípio do juiz natural é trazido pelos incs. XXXVII e LIII do art. $5^{\circ}$ da CF/88, que expressam: “Art. 5. (...) XXXVII - não haverá juízo ou tribunal de exceção; (...) LIII - ninguém será processado nem sentenciado senão pela autoridade competente" (BRASIL, 1988).

Logo, este princípio assegura dupla situação, pois, de um lado, impede a criação de tribunais de exceção e, de outro, impõe que o jurisdicionado seja julgado pela autoridade judiciária que tenha competência previamente definida ${ }^{2930}$. Aliás, há excelente doutrina defendendo que este princípio assegura uma terceira situação, que é a de um juiz imparcial ${ }^{31}$.

De modo harmônico ao princípio do juiz natural, o art. 97 da CF/88 estabeleceu a regra da reserva de plenário nos tribunais, ao expressar: "Somente pelo voto da maioria absoluta de seus membros ou dos membros do respectivo órgão especial poderão os tribunais declarar a inconstitucionalidade de lei ou ato normativo do Poder Público” (BRASIL, 1988).

Por meio desta regra, no âmbito dos tribunais, apenas a maioria absoluta dos seus membros ou de seu respectivo órgão especial é que poderá declarar a inconstitucionalidade de lei ou ato normativo.

Em outras palavras, embora o juiz de primeiro grau possa declarar a inconstitucionalidade de uma norma - nos tribunais -, onde vigora a regra da reserva de plenário, esta declaração apenas poderá ser feita pela maioria dos seus membros ou por meio de seu orgão especial ${ }^{32}$.

Desse modo, se um órgão fracionário do tribunal (turma ou câmara), estiver inclinado a declarar a inconstitucionalidade de determinada norma, deverá remeter os 
autos ao seu órgão especial. Após decidida esta questão constitucional, os autos retornam ao órgão fracionário para prosseguir com o julgamento observando a decisão do referido órgão especial.

O problema é que - para “driblar” esta regra -, alguns órgãos fracionários dos tribunais, ao se depararem com uma inconstitucionalidade, de um lado, não mencionavam que a norma era inconstitucional, mas, de outro lado, aplicavam o mesmo efeito da inconstitucionalidade, isto é, simplesmente "faziam de conta" que inexistia o comando trazido na referida norma.

Esta realidade foi retratada, por exemplo, em um dos recursos que o Supremo Tribunal Federal ${ }^{33}$ utilizou como paradigma para a criação da Súmula Vinculante $n^{\circ} 10$, onde se discutia a aplicação do artigo 272 do Decreto 2.637 de 1998, ao determinar que o maço de cigarros tenha 20 unidades. O acórdão impugnado nada dispôs sobre a sua inconstitucionalidade, bem como não aplicou o referido dispositivo, ao expressar que:

\begin{abstract}
Sem haver, sequer de leve, a menor intenção de demonstrar o impetrado qual o objetivo de sua exigência, qual o alcance de restrição ao comércio, qual a repercussão da quebra de restrição, não se pode chegar a outra conclusão senão a de que o Decreto n. 2.637, de 25/06/98, dispositivo no qual se apoiam os atos normativos impugnados, ao estabelecer como obrigatória a embalagem por vintena, violou o princípio da livre concorrência (art. 170, IV, da CF).
\end{abstract}

Ora, o fato de omitir que o referido art. 272 do Decreto 2.637/98 seria inconstitucional, não muda a realidade de que o mesmo não foi aplicado, porque o tribunal local entendeu que contrariava o inc. IV, do art. 170 da CF/88. Com base nesse entendimento, o Supremo Tribunal Federal deu provimento ao recurso para cassar o acórdão recorrido e determinar que a referida inconstitucionalidade fosse: "submetida ao órgão competente", ou seja, o órgão especial do Tribunal Local.

Vale advertir inicialmente que na cultura da "civil law", muitas vezes, as decisões judiciais não se preocupam em demonstrar os motivos que determinaram o resultado. Daí uma das principais dificuldades para localizar a "ratio decidendi" nos pronunciamentos brasileiros.

Ressalvado este aspecto, a referida Súmula Vinculante $\mathrm{n}^{\circ} 10$ expressa que:

Viola a cláusula de reserva de plenário ( $\mathrm{CF}$, artigo 97) a decisão de órgão fracionário de tribunal que, embora não declare expressamente a inconstitucionalidade de lei ou ato normativo do poder público, afasta sua incidência, no todo ou em parte. (GRIFO NOSSO) 
Reserva do plenário e a (in)segurança jurídica: análise da Súmula Vinculante número 10

Nesse contexto, não pode ser desprezado que esta súmula foi criada para evitar esta "declaração - diria - escamoteada de inconstitucionalidade ${ }^{34}$ ".

Assim, com o propósito de utilizar o máximo possível, no direito brasileiro, a teoria da "ratio decidendi" - e guardadas as devidas diferenças -, para aplicar esta súmula devem ser localizados os fundamentos antecedentes que conduziram ao resultado (consequente).

O resultado (consequente) que deve ser aplicado, se incidir a Súmula Vinculante $\mathrm{n}^{\circ} 10$, é a obrigação de observar a reserva de plenário.

Mas, para que seja aplicado este resultado (consequente), deve ser constatada a presença efetiva dos seus pressupostos (fatos antecedentes), que - neste caso -, podem ser extraídos do próprio corpo da súmula, a saber: primeiro, deve existir um julgamento por órgão fracionário de tribunal (câmaras ou turmas), que não seja o seu órgão especial; segundo, este julgamento deve envolver a inconstitucionalidade de uma lei ou ato normativo, que possa modificar o resultado do julgamento; terceiro, que este dispositivo, tido como inconstitucional, tenha sido deixado de ser aplicado.

Vale salientar que esta súmula é omissa quanto a outras situações que devem estar presentes para ela ser aplicada como, por exemplo: não pode ter existido decisão prévia sobre a norma pelo Tribunal; a norma questionada deve ter sido feita na vigência de Constituição atual $^{35}$; o órgão fracionário deve estar exercendo função jurisdicional (e não administrativa) ${ }^{36}$ e, por fim, a questão não pode versar sobre liminar ${ }^{37}$.

Logo, para aplicar esta súmula, a decisão judicial deverá demonstrar efetivamente a presença de todos estes pressupostos, conforme nossa proposta de redação para esta súmula, trazida no item subsequente. Contudo, uma vez demonstrados, deverá ser reconhecida a violação à cláusula de reserva de plenário, no caso concreto.

Com essa ordem de ideias, é possível propor uma nova redação para a referida súmula, nos termos abaixo:

Viola a cláusula de reserva de plenário ( $\mathrm{CF}$, artigo 97), quando o julgamento apresentar todos os fatos, a saber: a) proferido por órgão fracionário de tribunal; b) se referir à função jurisdicional do tribunal e não se tratar de 
liminar; c) versar sobre inconstitucionalidade de lei ou ato normativo que possa modificar o resultado do julgamento e tiver sido feita na vigência da atual Constituição Federal; d) afastar a incidência da referida lei ou ato normativo;d) que o tribunal ou seu órgão especial ainda não tenha se pronunciado sobre a referida inconstitucionalidade.

Este é o resultado da aplicação deste regra - obviamente guardadas as devidas peculiaridades -, que facilitariam muito se a Súmula Vinculante $\mathrm{n}^{\circ} 10$ trouxesse, mais claramente em seu corpo, todas as situações que devem estar presentes (antecedentes), para produzir o respectivo resultado (consequente).

Por fim, seria de boa técnica que a $\mathrm{CF} / 88$ fosse emendada para incluir um $\S$ $4^{\circ}$, no art. 103-B, contendo a obrigatoriedade de que a redação das súmulas vinculantes traga claramente todos os antecedentes (fundamentos determinantes) que devem estar presentes para produzir o resultado normatizado (consequente).

\section{CONSIDERAÇÕES FINAIS}

O problema problema lançado nesta pesquisa consiste na busca por um critério mais próximo possível da realidade brasileira, para alcançar a "ratio decidendi" da Súmula Vinculante $\mathrm{n}^{\circ} 10$.

Nesse contexto, o Brasil teve a sua cultura jurídica embasada na "civil law" e, por isso, poderia ser imaginado que a fonte originária do direito sempre tenha sido a lei. Entretanto, a história mostra que, há muito, têm sido usados mecanismos que são próprios da "common law".

Aliás, vale ressaltar que o apego aos precedentes, levaria maior isonomia aos jurisdicionados, bem como contribuiria com a segurança jurídica advinda da maior previsibilidade das decisões judiciais.

Daí a importância de se buscar, na cultura da "common law", uma de suas regras, que é a busca pela "ratio decidendi", ou seja, os fatos considerados pelo julgamento, que conduziram efetivamente ao resultado.

Porém, feito os devidos ajustes à realidade brasileira, este critério consiste em tornar mais explícitas as hipóteses de incidência da Súmula Vinculante $\mathrm{n}^{\mathbf{o}} 10$ (antecedentes), pois resultará na maior previsibilidade dos pronunciamentos judiciais sobre o tema (consequente), implicando a maior segurança jurídica e igualdade dos jurisdicionados 
Reserva do plenário e a (in)segurança jurídica: análise da Súmula Vinculante número 10

\section{REFERÊNCIAS}

ALMEIDA, Manuel; LOBÃO, Souza. Segundas linhas sobre o processo civil. $1^{\text {a }}$ ed. Lisboa: Imprensa Nacional, 1885.

BOBBIO, Norberto. O positivismo jurídico. Trad. por Carlos Rodrigues, Márcio Pugliesi e Edson Bini. 1a ed. São Paulo: Ícone, 1995.

BLACKSTONE, William. Commentaries on the law of England.. London: The University of Chigago Press. V. I., 1979.

BUSTAMANTE, Thomas da Rosa de. Precedent in Brazil. In: HONDIUS, Ewoud (org.). Precedent and the Law: Reports to the XVIIth Congress International Academy of Comparative Law Utrecht, 16-22 July 2006. Bruxelas: Bruylant, 2007.

Teoria do precedente judicial: a justificação e a aplicação de regras jurisprudenciais. São Paulo: Noeses, 2012.

CRUZ E TUCCI, José Rogério. Precedente judicial como fonte de direito. $1^{\text {a }}$ ed. São Paulo: Revista dos Tribunais, 2004, p. 12.

DAVID, René. Os grandes sistemas do direito contemporâneo, Trad. em português por Hermínio A. Carvalho. $1^{\text {a }}$ ed. São Paulo: Martins Fontes, 2002.

FRANZÉ, Luís Henrique Barbante. Teoria geral dos recursos e o novo Código de Processo Civil. $3^{a}$ ed. Curitiba: Juruá, 2016.

GOODHART, Arthur. Determining the ratio decidendi of a case. The Yale Law Journal. V. 40, nº 2, 1930.

GRINOVER, Ada Pellegrini. O princípio do juiz natural e sua dupla garantia. $\mathrm{O}$ processo em sua unidade. Rio de Janeiro: Forense, V. II, 1984.

HOLMES, Oliver Wendell. The common law - Lecture I. In: The common law \& other writings. Birmingham: The legal classics library, 1982.

KELSEN, Hans. Teoria pura do direito. Trad. João Baptista Machado. $1^{a}$ ed. São Paulo: Martins Fontes. 2009.

LIEBMAN, Enrico Tullio. Manuale di diritto processuale civile. $4^{\mathrm{a}}$ ed. Milão: Giuffrè, V. I, 1984.

MANCUSO, Rodolfo de Camargo. Divergência jurisprudencial e súmula vinculante. $3^{\text {a }}$ ed. São Paulo: Revista dos Tribunais, 2007.

MARINONI, Luiz Guilherme. Precedentes obrigatórios. $3^{a}$ ed. São Paulo: Revista dos Tribunais, 2013. 
MONTESQUIEU, Charles de Secondat. Do espírito das leis. Trad. Fernando Henrique Cardoso e Leôncio Martins Rodrigues. $2^{a}$ ed. São Paulo: Abril Cultural, 1979.

NERY JÚNIOR. Nelson. Princípios do processo na Constituição Federal. $12^{a}$ ed. São Paulo: Revista dos Tribunais. 2016.

NERY JÚNIOR. Nelson; NERY, Rosa Maria de Andrade. Código de processo civil comentado. 9 ed. São Paulo: Revista dos Tribunais. 2006.

POUND, Roscoe. What is the common law? The University of Chicago Law Review. $1937, \mathrm{n}^{\circ} 4$.

TALAMINI, Eduardo. Recorribilidade das decisões sobre tutela de urgência: a suposta discricionariedade; efeito suspensivo e ativo; recorribilidade das decisões do relator; antecipação de tutela e a apelação contra sentença final. In: NERY JÚNIOR, Nelson; WAMBIER, Teresa Arruda Alvim. (Org.). Aspectos polêmicos e atuais dos recursos cíveis e de outras formas de impugnação às decisões judiciais. $1^{\mathrm{a}}$ ed. São Paulo: Revista dos Tribunais, V. IV. 2001, págs. 267-298.

TARANTO, Caio Márcio Gutterres. Precedente judicial: Autoridade na jurisdição constitucional. 1 ed. Rio de Janeiro: Forense, 2010.

TARUFFO, Michele. Precedente e jurisprudência. Colômbia: Revista Precedente da Faculdade de Direitos e Ciências Sociais, 2007, p. 87-89.

TUCCI, José Rogério Cruz. Precedente judicial como fonte de direito. 1 ed. São Paulo: Revista dos Tribunais, 2004.

SOUZA, Marcelo Alves Dias de. Do precedente judicial à súmula vinculante. $1^{\mathrm{a}}$ ed. Curitiba: Editora Juruá, 2013.

Artigo recebido em 05 de fevereiro de 2017 e aceito em 16 de março de 2018

1 Casos semelhantes devem ser julgados de forma semelhante.

R. Fac. Dir. UFG, v. 42, n. 3, p.225-247, set./dez. 2018 
2 Com o propósito de realizar a justiça formal, ao tratar igualmente os casos semelhantes.

3 Importante salientar que o sistema do "stare decisis" - que passou a ser usado na "common law" para obrigar o cumprimento dos precedentes -, possui exceções, como ocorre quando se demonstra que o caso examinado é diverso ("distinguishing"), ou se demonstra que o entendimento do precedente está superado ("overruling").

4 José Rogério Cruz e Tucci adverte que o substantivo jurisprudência indica a atividade desenvolvida pelo tribunal para "dizer o direito", além de que, no decorrer da história, já existiram outros inúmeros significados, ao expressar que: "Optamos deliberadamente pelo emprego da locução precedente judicial em substituição ao termo jurisprudência, de uso mais comum e nossa linguagem jurídica, por duas relevantes razões. Em primeiro lugar porque, enquanto hoje o substantivo jurisprudência indica genericamente a atividade dos tribunais no desempenho de seu mister 'ius dicere', no âmbito da história do direito, 'iurisprudentia' tem múltiplo significado, ora indicando ciência do direito, ora designando a própria atividade profissional (jurisprudência forense ou prática contraposta à teórica)" (2004, p. 15).

5 Esta racionalidade é lembrada por Caio Márcio Gutterres Taranto - com apoio na doutrina de Geoffrey Marshall -, que adverte sobre a possibilidade de a terminologia precedente ser usado para outras aplicações. Como: "Primeiro, é, às vezes, utilizada sem promover consideração ou análise de um corpo de alegações relevantes de decisões anteriores. Em segundo lugar, 'precedente' pode ser utilizada como uma descrição de um resultado de uma dada decisão que é considerada por sua relevância. Por fim, leciona o Professor de Oxford que a terminologia pode ser usada para estabelecer uma regra abstrata que, para a decisão em um caso particular, é arguida para exemplificar ou ilustrar." (TARANTO, 2010, p. 8).

6 Sobre a "força gravitacional do precedente judicial” ver Bustamante, 2012, p. 302

7 "o obter dictum corresponde ao enunciado, interpretação jurídica, ou uma argumentação ou fragmento de argumentação jurídica, expressamente contidos na decisão judicial, cujo conteúdo e presença são irrelevantes para a solução final da demanda". (STRECK, 2013, p. 44).

8 Sobre estas regras, Marcelo Alves Dias de Souza expressa que: "Ao final, Goodhart resume as regras para se determinar a 'ratio decidendi' de um caso da seguinte forma: (1) O princípio de um caso não é encontrado nas razões dadas na opinion. (2) O princípio não é encontrado na regra de Direito apresentada na opinion. (3) O princípio não é necessariamente encontrado através de uma consideração de todos os fatos averiguados do caso e da decisão do juiz. (4) $\mathrm{O}$ princípio do caso é encontrado ao se levarem em conta (a) os fatos tratados pelo juiz como fundamentais, e (b) sua decisão como baseada neles. (5) Para encontrar o princípio, também, é necessário estabelecer quais fatos foram considerados não fundamentais pelo juiz, pois o princípio pode depender tanto da exclusão como da inclusão." (2013, p. 133).

9 Embora os limites desta pesquisa impede o aprofundamento sobre estas teorias, vale registrar que Arthur Goodhart chegou a argumentar que poderiam existir decisões em que a "ratio decidendi" não estaria nos fundamentos. (1930, p. 167).

10 Guardadas as devidas proporções, Hans Kelsen bem salienta a recriação do direito por meio desta relação entre antecedente e consequente, ao expressar: "Para individualizar a norma geral por ele aplicada, o tribunal tem de verificar se, no caso que se lhe apresenta, existem 'in concreto' os pressupostos de uma consequência do ilícito determinados 'in abstracto' por uma norma geral. Esta determinação do fato que condiciona as consequências do ilícito implica a 
determinação da norma geral a aplicar, isto é, a averiguação de que está em vigor uma norma geral que liga uma sanção ao fato (ou situação de fato) em apreço.” (2009, p. 263-264).

11 Como ressalta Thomas da Rosa de Bustamante, na França, este método de aplicação do direito é conhecido como phrase unique, que é resultado de uma forte influência do positivismo formalista, da escola da Exegese, que pretendia "reduzir o direito à lei" (2012, pág 20).

12 Nestes sistemas, os códigos representam uma evolução, pois têm o escopo de facilitar a aplicação da lei, ao separá-las geograficamente pelas matérias que regulamentam. Por exemplo, a Constituição Federal Brasileira adverte que a fonte primária de nosso direito seria a lei, conforme expresso, principalmente, no art. $5^{\circ}$, inc. II, da CF, ao expressar que: "ninguém será obrigado a fazer ou deixar de fazer alguma coisa senão em virtude de lei; (...)”

13 Este critério da "civil law" foi superado pela filosofia da linguagem, quando as concepções essencialista da língua foi superado pela concepção convencionalista, devido a concepção kantiana e, mais atualmente, com o giro linguístico formulado por Martin Heidegger.

14 Com o propósito de a decisão judicial tenha limites e seja legitimada, o que deve ser feito de forma discursivo-argumentativo e racional.

15 Constituição de 1824, Art. 15: "É da atribuição da Assembléa Geral. (...) VIII. Fazer Leis, interpreta-las, suspende-las, e rovoga-las."

16 Constituição de 1824, Art. 101: "O Imperador exerce o Poder Moderador I. Nomeando os Senadores, na fórma do Art. 43. II. Convocando a Assembléa Geral extraordinariamente nos intervallos das Sessões, quando assim o pede o bem do Imperio. III. Sanccionando os Decretos, e Resoluções da Assembléa Geral, para que tenham força de Lei: Art. 62. IV. Approvando, e suspendendo interinamente as Resoluções dos Conselhos Provinciaes: Arts. 86, e 87. V. Prorogando, ou adiando a Assembléa Geral, e dissolvendo a Camara dos Deputados, nos casos, em que o exigir a salvação do Estado; convocando immediatamente outra, que a substitua. VI. Nomeando, e demittindo livremente os Ministros de Estado. VII. Suspendendo os Magistrados nos casos do Art. 154. VIII. Perdoando, e moderando as penas impostas e os Réos condemnados por Sentença. IX. Concedendo Amnistia em caso urgente, e que assim aconselhem a humanidade, e bem do Estado.".

17 Originário dos Estados Unidos da América, o controle difuso ("judicial review") restringe às partes, o alcance da decisão proferida no processo de modo que afeta apenas obrigação discutida nos autos. Ao contrário, pelo controle concentrado (modelo originário da Europa), a decisão proferida nos autos alcança a norma (e não apenas a obrigação), valendo para todos (e não apenas para as partes).

18 Constituição de 1891, Art. 59: “(...) II: “julgar, em grào de recurso as questões excedentes da alçada legal resolvidas pelos Juízes e Tribunais Federais;”

19 Constituição de 1937, Art. 96: "Só por maioria absoluta de votos da totalidade dos seus Juízes poderão os Tribunais declarar a inconstitucionalidade de lei ou de ato do Presidente da República. Parágrafo único: No caso de ser declarada a inconstitucionalidade de uma lei que, a juízo do Presidente da República, seja necessária ao bem-estar do povo, à promoção ou defesa de interesse nacional de alta monta, poderá o Presidente da República submetê-la novamente ao exame do Parlamento: se este a confirmar por dois terços de votos em cada uma das Câmaras, ficará sem efeito a decisão do Tribunal."

20 Código de Processo Civil de 1939, Art. 861: “A requerimento de qualquer de seus juizes, a Câmara, ou turma julgadora, poderá promover o pronunciamento prévio das Câmaras reunidas 
sobre a interpretação de qualquer norma jurídica, se reconhecer que sobre ela ocorre, ou poderá ocorrer, divergência de interpretação entre Câmaras ou turmas."

21 Código de Processo Civil de 1973, Art. 479: "O julgamento, tomado pelo voto da maioria absoluta dos membros que integram o tribunal, será objeto de súmula e constituirá precedente na uniformização da jurisprudência."

22 No Brasil, o ativismo é muito usado, por exemplo, para obrigar o poder público a cumprir a sua obrigação de entregar remédios vitais para o cidadão.

23 Lei 8.038/90, Art. 38: "O Relator, no Supremo Tribunal Federal ou no Superior Tribunal de Justiça, decidirá o pedido ou o recurso que haja perdido seu objeto, bem como negará seguimento a pedido ou recurso manifestamente intempestivo, incabível ou, improcedente ou ainda, que contrariar, nas questões predominantemente de direito, Súmula do respectivo Tribunal."

$24 \mathrm{CF} / 88$, Art. 102. (...) $\S 2^{\circ}$ : “As decisões definitivas de mérito, proferidas pelo Supremo Tribunal Federal, nas ações declaratórias de constitucionalidade de lei ou ato normativo federal, produzirão eficácia contra todos e efeito vinculante, relativamente aos demais órgãos do Poder Judiciário e ao Poder Executivo."

25 CF/88, Art. 103-A: "O Supremo Tribunal Federal poderá, de ofício ou por provocação, mediante decisão de dois terços dos seus membros, após reiteradas decisões sobre matéria constitucional, aprovar súmula que, a partir de sua publicação na imprensa oficial, terá efeito vinculante em relação aos demais órgãos do Poder Judiciário e à administração pública direta e indireta, nas esferas federal, estadual e municipal, bem como proceder à sua revisão ou cancelamento, na forma estabelecida em lei."

26 Relevante registrar que o legislador adotou o sistema mais rigoroso da maioria qualificada de $2 / 3$ para a súmula vinculante e, por conseguinte, continuou a maioria absoluta para as demais súmulas (não vinculantes). A diferença entre as três formas de auferir o quorum, a saber: a) Maioria simples é auferida pelo primeiro número inteiro acima da metade dos presentes. Logo se existem 11 ministros, e apenas 7 comparecem, a maioria simples será 4 votos; b) Maioria absoluta é auferida pelo primeiro número inteiro acima da metade dos membros (e não dos presentes) do respectivo órgão. Logo se existem 11 ministros, e apenas 7 comparecem, a maioria absoluta será 6 votos; c) Maioria qualificada é auferida pelo primeiro número inteiro acima da fração indicada (geralmente é de 2/3), dos membros do respectivo órgão. Logo se existem 11 ministros, a maioria qualificada de $2 / 3$ será 8 votos.

$27 \mathrm{CF} / 88$, Art. 103-A, § 3: "Do ato administrativo ou decisão judicial que contrariar a súmula aplicável ou que indevidamente a aplicar, caberá reclamação ao Supremo Tribunal Federal que, julgando-a procedente, anulará o ato administrativo ou cassará a decisão judicial reclamada, e determinará que outra seja proferida com ou sem a aplicação da súmula, conforme o caso.”

28 Lei 9.784/99, Art. 64-B: “Acolhida pelo Supremo Tribunal Federal a reclamação fundada em violação de enunciado da súmula vinculante, dar-se-á ciência à autoridade prolatora e ao órgão competente para o julgamento do recurso, que deverão adequar as futuras decisões administrativas em casos semelhantes, sob pena de responsabilização pessoal nas esferas cível, administrativa e penal."

29 Ada Pellegrini Grinover também defende esta dupla garantia do princípio natural (1984, pág 20). 
30 A definição de que o juiz natural corresponde ao juízo constituído previamente pela lei também é trazida por Enrico Tullio Liebman (1984, pág. 09).

31 Esse é o posicionamento de Nelson Nery Júnior, ao expressar: "A garantia do juiz natural é tridimensional. Significa que: 1) não haverá juízo ou tribunal `ad hoc', isto é, tribunal de exceção; 2) todos têm o direito de se submeter a julgamento (civil ou penal) por juiz competente, pré-constituído na forma da lei; 3 ) o juiz competente tem de ser imparcial." (2016, pág 162).

32 Vale salientar que, nos tribunais, o juiz natural assegura que os julgamentos sejam feitos pelo Colegiado, que decorre de regra implícita da estrutura Constitucional do Poder Judiciário. Nesse sentido, Eduardo Talamini (2001, pág. 288) e Luís Henrique Barbante Franzé (2016, pág. 108).

33 Supremo Tribunal Federal, Primeira Turma, Recurso extraordinário 319.181-1, Rel. Min. Ellen Gracie, DJ 28.06.2002, com ementa expressando: "Controle de constitucionalidade: reserva de plenário (art. 97 da Constituição Federal). Inobservância. Recurso extraordinário conhecido e provido, para cassar a decisão recorrida, a fim de que seja a questão da inconstitucionalidade submetida ao órgão competente."

34 Esta frase foi extraída da manifestação do Ministro Marco Aurélio durante os debates que integram a ata de criação da Súmula Vinculante $n^{\circ}$ 10, realizada no dia 18/06/2008, [http://www.stf.jus.br/arquivo/cms/jurisprudenciaSumulaVinculante/anexo/DJe_172_2008.pdf], acesso em 24/04/2014.

35 Supremo Tribunal Federal, Primeira Turma, Agravo regimental no agravo de instrumento 808.037, Rel. Min. Luiz Fux, DJe 19.03.2013, com ementa expressando: "AGRAVO REGIMENTAL NO AGRAVO DE INSTRUMENTO. CONSTITUCIONAL. EMPRÉSTIMO COMPULSÓRIO. LEI 4.156/62. DEVOLUÇÃO. ALEGAÇÃO DE VIOLAÇÃO A CLÁUSULA DE RESERVA DE PLENÁRIO (ARTIGO 97 DA CONSTITUIÇÃO FEDERAL). INOCORRÊNCIA. NORMA ERIGIDA SOB A ÉGIDE DA CONSTITUIÇÃO ANTERIOR. RECEPÇÃO DA LEI POR ÓRGÃO FRACIONÁRIO. POSSIBILIDADE. MATÉRIA INFRACONSTITUCIONAL RECONHECIDA PELO PLENÁRIO VIRTUAL DO STF NO AI-RG N. 810.097. 1. A cláusula de reserva de plenário (full bench) é aplicável somente aos textos normativos erigidos sob a égide da atual Constituição. 2. As normas editadas quando da vigência das Constituições anteriores se submetem somente ao juízo de recepção e não pela atual ordem constitucional, o que pode ser realizado por órgão fracionário dos Tribunais sem que se tenha por violado o art. 97 da CF. Precedentes: AI-AgR 582.280, Segunda Turma, Rel. Min. Celso de Mello, DJ 6.11.2006 e AI 831.166-AgR, Segunda Turma, Rel. Min. Gilmar Mendes, Dje de 29.4.2011. 3. O Plenário Virtual do STF, nos autos do AI-RG 810.097, afastou a repercussão geral relativa ao tema, por se tratar de matéria restrita ao âmbito infraconstitucional. 4. Agravo regimental a que se nega provimento."

36 Supremo Tribunal Federal, Reclamação 15.287, Rel. Min. Celso de Mello, DJe 03.10.2013, decisão monocrática com trecho expressando: "É que a alegação de desrespeito à exigência constitucional da reserva de plenário ( $\mathrm{CF}$, art. 97) supõe, para restar configurada, a existência de decisão emanada de autoridades ou órgãos judiciários proferida em sede jurisdicional. Assinalo, no entanto, que o Conselho da Magistratura do E. Tribunal de Justiça do Estado do Paraná, no âmbito de suas atribuições, exerce atividade de caráter eminentemente administrativo, circunstância essa que descaracteriza, por completo, a alegação de desrespeito ao enunciado constante da Súmula Vinculante n ${ }^{\circ} 10 /$ STF." 
Reserva do plenário e a (in)segurança jurídica: análise da Súmula Vinculante número 10

37 Supremo Tribunal Federal, Tribunal Pleno, Agravo regimental na Reclamação 10.864, Rel. Min. Carmen Lúcia, DJe 13.04.2011, com ementa expressando: "1. Indeferimento de medida cautelar não afasta a incidência ou declara a inconstitucionalidade de lei ou ato normativo. 2. Decisão proferida em sede cautelar: desnecessidade de aplicação da cláusula de reserva de plenário estabelecida no art. 97 da Constituição da República." 